\title{
PERTANIAN ORGANIK SEBAGAI BENTUK TANGGUNG JAWAB MANUSIA TERHADAP LINGKUNGANNYA DITINJAU DARI KEJADIAN 2:15
}

\author{
Patrisius Tauho \\ petrustauho@gmail.com \\ Sekolah Tinggi Teologi Jemaat Kristus Indonesia
}

\begin{abstract}
Since God created the universe, humans were placed in the garden of Eden, God invited humans to be involved in the care of His creation. Organic farming is a manifestation of human responsibility to care for the environment. Essentially man cannot be separated from the natural surroundings because he was created as part of the cosmos created by God. Based on Genesis 2:15, it will be known how agricultural technology must be developed to care for and protect not destroy nature. Humans are invited to be involved in the maintenance of creation.
\end{abstract}

Keywords: organic, environment, cosmos

\begin{abstract}
ABSTRAK
Sejak Allah menciptakan alam semesta, manusia ditempatkan di dalam taman Eden, Allah mengajak manusia untuk terlibat dalam pemeliharaan ciptaan-Nya. Pertanian organik merupakan salah satu perwujudan tanggung jawab manusia merawat lingkungannya. Secara esensi manusia tidak bisa lepas dari alam sekitar karena dia dciptakan sebagai bagian dari kosmos yang diciptakan Tuhan. Berdasar Kejadian 2:15 akan diketahui bagaimana teknologi pertanian harus dikembangkan untuk merawat dan menjaga bukan merusak alam. Manusia diundang untuk terlibat dalam usaha pemeliharaan ciptaan.
\end{abstract}

Kata kunci: organik, lingkungan, kosmos

\section{PENDAHULUAN}

Pertanian organik merupakan kegiatan bercocok tanam ramah lingkungan. Hal itu merupakan cara keterlibatan manusia dalam menjaga dan melestarikan karya Allah. Allah pada mulanya menciptakan tumbuh-tumbuhan dan memberi-kan kuasa kepada manusia untuk mengelola dan mengusahakannya seperti yang tertulis di dalam Kejadian 2:15 "Tuhan Allah mengambil manusia dan menempatkannya dalam taman Eden untuk mengusahakan dan memelihara taman itu". 
Dengan demikian usaha manusia mengelola taman itu dalam istilah masa kini disebut sebagai petani dan lahan yang ia kelola disebut pertanian.

Secara tersirat, Alkitab menyatakan bahwa Allah adalah inisiator pertanian itu. la pada mulanya menciptakan tumbuh-tumbuhan dengan baik adanya, seperti yang tertulis di dalam Kejadian 1:11-12 Berfirmanlah Allah: "Hendaklah tanah menumbuhkan tunas-tunas muda, tumbuh-tumbuhan yang berbiji, segala jenis pohon buah-buahan yang menghasilkan buah yang berbiji supaya ada tumbuh-tumbuhan di bumi." Dan jadilah demikian. Tanah itu menumbuhkan tunas-tunas muda, segala jenis tumbuh-tumbuhan yang berbiji dan segala jenis pohon-pohon yang menghasilkan buah yang berbiji. Allah melihat bahwa semuanya itu baik." Ini menunjukan bahwa Allah adalah inisiator pertanian itu atau dapat dikatakan bahwa Allah adalah petani pertama. Sungguh apa yang dikerjakan oleh Allah itu baik adanya. Semua yang dilakukan Allah dalam penciptaan semata-mata untuk kepentingan kebaikan manusia. Matthew Henry dalam komentarnya mengatakan bahwa Tuhan memberikan bumi kepada manusia dengan merancangnya menjadi tempat tinggal yang nyaman bagi mereka ("God gave the earth to the children of men, designing it to be a comfortable dwelling to them)"

Cerita di atas kemudian berubah pada waktu manusia jatuh ke dalam dosa. Kejadian 3:17-19a menceritakan bahwa akibat ketidak taatan manusia, tanah dikutuk oleh Allah sehingga dengan berpeluh manusia akan mencari makanannya sampai ia kembali menjadi tanah. Ronald L. Toruan dalam tulisannya sehubungan dengan dampak kejatuhan manusia dalam dosa mengatakan, "semula manusia diberikan mandat untuk mengelola, memelihara dan menata dan memiliki hubungan interdependensi yang erat dan kuat (Kejadian 1:28). Namun dosa membuat manusia bukannya memelihara tetapi cenderung merusak alam demi kepentingan sendiri." Dengan demikian dapat disimpulkan bahwa kejatuhan itu mengakibatkan manusia egois, sehingga melihat ciptaan lain sebagai objek yang dapat di eksploitasi demi kepentingannya sendiri; eksploitasi alam pertanian melalui rekayasa genetik dan penerapan kimia sintetis misalnya.

\section{METODE PENELITIAN}

Metode penelitian yang peneliti gunakan dalam penulisan artikel in, yaitu metode kualitatif dengan pendekatan deskriptif. Dalam pendekatan deskriptif peneliti akan meneliti tentang tanggung jawab manusia berdasarkan Kejadian

\footnotetext{
${ }^{1}$ Matthew Henry: Commentary on the whole bible Volume 1 (Grand Rapids, MI: Christian Classics Ethereal Library) 66

${ }^{2}$ https://www.kompasiana.com/ronald_toruan Diakses di STTJKI, 17/07/2019 pukul 13.00
} 
2:15, dalam pembangunan teori peneliti akan meneliti dan mengeksegesa Kitab Kejadian 2:15 sehingga peneliti dapat menemukan tentang tanggung jawab manusia serta bagaimana menjalankan tugas tersebut. Dengan demikian peneliti dapat menyimpulkan bahwa adalah wajib bagi manusia untuk melestarikan lingkungan hidup sebagaimana dijelaskan dalam kejadian 2:15.

\section{PEMBAHASAN DAN HASIL}

\section{Pengertian Lingkungan Hidup Secara Umum}

Lingkungan hidup adalah tempat dimana manusia itu hidup yang di dalamnya terdapat kehidupan lain yang sifatnya "saling" atau yang biasa dikenal sebagai simbiosis mutualisme. Hal ini tidak hanya berlaku antara manusia dan manusia, melainkan manusia dan segala sesuatu yang ada dalam lingkungan tersebut. Menurut Kamus Offline Bahasa Indonesia, Lingkungan hidup didefinisikan sebagai "Kesatuan ruang dengan semua benda..."3 Senada dengan definisi KBBI di atas, Sonny Keraf memperjelas dengan mengatakan bahwa:

Lingkungan hidup dalam bahasa Yunani adalah Oikos yang berarti habitat atau tempat tinggal. Oikos dipahami sebagai keseluruhan alam semesta dan seluruh interaksi saling pengaruh yang terjalin di dalamnya di antara makhluk hidup dengan makhluk hidup lainnya dan dengan keseluruhan ekosistem atau habitat. Dengan demikian, lingkungan hidup dipahami sebagai ekosistem, tempat makhluk hidup termasuk manusia tinggal yang merupakan sebuah sistem yang terikat satu sama lain dan terus berkembang secara dinamis. ${ }^{4}$

Dunia sebetulnya adalah tempat yang sangat baik yang diciptakan Tuhan untuk manusia dapat tinggal dengan nyaman, sebagaimana yang diungkapkan oleh Matthew Henry dalam komentarnya bahwa Tuhan memberikan bumi kepada manusia dengan merancangnya menjadi tempat tinggal yang nyaman bagi mereka ("God gave the earth to the children of men, designing it to be a comfortable dwelling to them)" dalam sebuah jurnal Sosial Humaniora dikatakan bahwa "manusia sebetulnya sedang tinggal di dalam alam sebagai "home of light" Artinya, bahwa sebetulnya lingkungan dimana manusia tinggal adalah satu tempat yang sungguh amat baik sebagaimana yang

\footnotetext{
3 Kamus Bahasa Indonesia Offline, diakses pada hari Sabtu, 18 April 2020 di Plalar, jam 16.50

${ }^{4}$ Sonny Keraf, Etika Lingkungan Hidup, (Yogyakarta: Kanisius, 2014) 42-43

${ }^{5}$ Matthew Henry: Commentary on the whole bible Volume 1 (Grand Rapids: Michigan: Christian Classics Ethereal Library) 66

6 Jurnal Sosial Humaniora (JSH) Menjadi Manusia Spiritual-Ekologis di Tengah Krisis Lingkungan [2019], Volume 12. Hal 46
} 
diciptakan oleh Tuhan pada awalnya. Allah melihat segala yang dijadikan-Nya itu, sungguh amat baik...(Kejadian 1:31).

\section{Lingkungan Hidup Tradisional}

Lingkungan hidup tradisional yang dimaksudkan peneliti dalam bagian ini adalah lingkungan pada zaman dimana teknologi belum berkembang atau biasa disebut sebagai zaman neolitik. Satu zaman dimana manusia dan alam sangat harmonis.

\section{Manusia Setara dengan Alam}

Zaman tradisional adalah satu zaman dimana manusia memposisikan dirinya sebagai bagian yang sangat kecil atau mikrokosmos di tengah kehidupan lingkungan biologis lainnya yaitu alam sebagai makrokosmos. Robert P. Borrong mengatakan bahwa:

Manusia sering melihat dirinya lebih kecil... paham ini dianut baik oleh filsafat maupun agama kuno yang selalu melihat hubungan yang harmonis antara manusia dengan alam. Manusia berusaha menyesuaikan diri dan menyelaraskan irama kehidupannya dengan alam, dengan cara menyesuaikan diri dengan musim dalam pertanian dan tidak berani mengganggu lingkungannya, kecuali melalui upacara dan ritual. $^{7}$

Sikap orang-orang tradisional dalam memperlakukan alam itu baik, namun kurang tepat bila ditinjau secara teologis, sebab manusia sebenarnya diciptakan lebih tinggi derajatnya dari ciptaan lainnya sehingga apabila manusia harus melihat dirinya lebih kecil dari ciptaan lainnya dengan maksud memperlakukan alam sebagai Tuhannya, maka hal itu adalah kesalahan yang fatal sebab ada pribadi metafisik yang menciptakan bumi dan segala isinya termasuk manusia yang kepadanya manusia itu harus menyembah. Namun, bagaimanapun sikap di atas merupkan sikap positif yang harus di tiru dan diterapkan oleh manusia jaman moderen ini apabila sikap di atas diterapkan sebagai suatu etika ekologis serta memahami bahwa kesehatan segala aspek ekologi kehidupan merupakan kunci kenyamanan hidup manusia sebagaimana yang telah diciptakan oleh pribadi metafisik tersebut.

\subsection{Manusia Menguasai Alam}

Seiring berjalannya waktu teknologi tradisional perlahan berubah dari memanfaatkan tenaga manusia berubah menjadi tenaga mesin atau yang dikenal sebagai teknologi moderen. Dengan kemampuan mesin manusia mampu untuk menguasai alam sesuai keinginannya. Teknologi moderen ini memungkinkan manusia mengubah lingkungan alamiah menjadi lingkungan

\footnotetext{
${ }^{7}$ Robert P. Borrong, Etika Bumi Baru, (Jakarta, Gunung Mulia, 2003) 26.
} 
buatan, hutan diubah menjadi lahan pertanian, tempat pemukiman dan lain sebagainya. Manusia kini dapat mengubah alam sesuai kebutuhannya. Akibatnya ilmu pengetahuan dan teknologi digunakan untuk mengeksploitasi alam dan eksploitasi itu pun menjadi tak terbatas.

Pengeksploitasian tak terbatas itulah yang menjadi akar krisis lingkungan, karena manusia mengambil hasil alam lebih dari yang dibutuhkannya dan dengan demikian proses daur alam akan terganggu. Dalam hal ini, hubungan manusia dengan alam menjadi hubungan hirarkis dan tidak mencerminkan lagi kesatuan, keharmonisan, keselarasan dan keseimbangan antara manusia dengan alam, dimana pada masa teknologi tradisional manusia memposisikan dirinya sebagai mikrokosmos namun pada era teknologi moderen manusia justru memposisikan dirinya sebagai makrokosmos.

\subsection{Lingkungan Hidup Modern}

Lingkungan hidup moderen yang dimaksudkan peneliti dalam penulisan ini adalah lingkungan yang awalnya dilihat sebagai "economic needs menjadi economic wants"8 Artinya bahwa apabila manusia tradisional melihat lingkungan sebagai tempat dimana mereka dapat memenuhi kebutuhan mereka sementara manusia moderen melihat lingkungannya sebagai tempat pemuas nafsu mereka. Penulis jurnal sosial humaniora mengatakan:

Manusia hidup dengan penuh kerakusan dan keserakahan, hidup tak pernah mengenal kata-kata "aku sudah cukup"! Manusia bernafsu memburu/memenuhi kata-kata "aku harus memiliki lebih banyak karena merasa belum cukup memiliki lebih banyak"! Manusia bermental hedonis, konsumtif, konsumeristis, tidak peduli dan berkompetisi untuk mengumpulkan akumulasi kekayaan material dalam jargon 'memiliki lebih banyak dalam hidup itu lebih baik daripada memiliki sedikit/kurang9 .

Pernyataan di atas merupakan fakta era moderen ini, yang berakibatkan pada eksploitasi secara besar-besaran sebagaimana yang diungkapkan oleh Borrong bahwa "teknologi memungkinkan manusia dapat mengubah lingkungan alamiah menjadi lingkungan buatan, misalnya hutan diubah menjadi tanah pertanian, pemukiman dan sebagainya"10 Mengutip pernyataan Franz Magnis-Suseno, Borrong mengatakan bahwa semuanya ini dilakukan dengan dasar "ideologi pertumbuhan"11 Dengan demikian, kegiatan yang sifatnya eksploitatif akan terus berlangsung.

$8 \mathrm{lbid}, 43$

9 Jurnal Sosial Humaniora (JSH) Menjadi Manusia Spiritual-Ekologis Di Tengah Krisis Lingkungan [2019], Volume 12. Hal 46

${ }^{10}$ Borrong, 31

${ }^{11} \mathrm{lbid}, 47$ 


\section{Teknologi}

Secara definisi, teknologi tidak sekedar berbicara soal penemuan alat-alat berat, ataupun mesin-mesin yang mampu mempercepat kegiatan manusia, melainkan lebih luas dari itu dimana berbicara tentang bagaimana manusia berusaha untuk memberikan kemudahan dan kenyamanan bagi dirinya.

Kamus Bahasa Indonesia Offline memberikan definisi teknologi sebagai "keseluruhan sarana untuk menyediakan barang-barang yang diperlukan bagi kelangsungan dan kenyamanan hidup manusia"12. Sebab itu, manusia kemudian beralih dari zaman revolusi neolitik kepada zaman revolusi industri.

Arnold. Gehlen dalam bukunya Man in the Age of Technology, dikutip dalam sebuah karya tulis mendefinisikan keduanya sebagai berikut: "Revolusi neolitik: Manusia beralih dari hidup mengembara dan berburu ke keadaan hidup menetap dengan mengembangkan pertanian dan pemeliharaan hewan; sementara revolusi industri adalah: berkembangnya kebudayaan mesin yang memenuhi kebutuhan manusia dan mengubah tatanan hidupnya"13. Sehingga dapat disimpulkan bahwa sumber teknologi itu adalah manusia itu sendiri yang terus berusaha untuk memberikan kemudahan dan kenyamanan bagi dirinya sendiri.

Lukman Santoso dalam tulisannya terkait dengan teknologi, mengatakan bahwa: "setiap penemuan dan perkembangan teknologi yang digunakan di satu zaman pasti akan disempurnakan pada zaman berikutnya"14. Oleh sebab itu, teknologi semakin hari akan semakin dikembangkan demi memenuhi kebutuhan dan kenyamanan manusia. Salah satunya adalah teknologi pertanian. Lukman Santoso meneruskan penjelasannya bahwa "Perkembangan teknologi semakin memuncak setelah Perang Dunia ke Il yang membawa dampak baik dalam banyak aspek. Baik itu industri, ekonomi, sosial, agama, pertahanan dan tanpa terkecuali terhadap pertanian"15 Istilah yang digunakan dalam revolusi pertanian dikenal sebagai "revolusi hijau" 16

\section{Dampak Teknologi}

Dampak positif perkembangan teknologi adalah mempercepat dan mempermudah manusia dalam rangka memenui kebutuhan hidupnya. Thomas

\footnotetext{
12 Kamus Besar Bahasa Indonesia Offline, diakses pada hari Sabtu, 18/04/2020 di Plalar, pukul 16.50

${ }^{13} \mathrm{https}$ ///arydj.files.wordpress.com/2009/12/01-pengertian-teknologi.pdf. Diakses di Plalar pada hari Sabtu, 18/04/2020, pukul 16.15

${ }^{14}$ L. Santoso A.Z. Para Penggerak Revolusi, (Yogyakarta: Laksaan, 2017) 499

$15 \mathrm{lbid}, 499-500$

${ }^{16}$ https://www.katailmu.com/2013/06/revolusi-hijau.html. Diakses di Plalar pada hari Sabtu, 18/04/2020 jam 16.30
} 
Robert Malthus (1766-1834) pencetus gagasan revolusi hijau, mengatakan bahwa "pertumbuhan jumlah penduduk sangat pesat dan tidak sebanding dengan pertumbuhan pangan"17. Sebab itu diperlukannya suatu revolusi dalam hal pertanian demi menyeimbangkan dan memenuhi kebutuhan pangan manusia. Akibat pernyataan Malthus, terjadilah kegemparan di Eropa dan AS sehingga munculah sebuah gerakan pengembangan pertanian dengan sebutan revolusi hijau. "Revolusi hijau mendasar dari empat pilar diantaranya: penyediaan air melalui irigasi, pemakaian pupuk kimia secara optimal, penerapan pestisida sesuai dengan tingkat serangan organisme pengganggu tanaman (OPT) dan penggunaan varietas unggul sebagai bahan tanam berkualitas"18

Akibat revolusi hijau tersebut, "petani tidak lagi bergantung pada musim dan alam"19 dan hasilnya sangat spektakuler. Lukman Santoso, terkait dengan peningkatan hasil pangan akibat penerapan technofarm, mengatakan bahwa "melalui revolusi hijau tersebut ditemukannya berbagai varietas bibit unggul sehingga menghasilkan produksi padi dan gandum meningkat sehingga memenuhi kebutuhan pangan di berbagai negara" 20 bahkan "Indonesia sendiri mampu swasembada beras dan bisa mengekspor beras ke India"21

Fakta di atas menunjukan bahwa teknologi sangat penting bagi manusia dan karena itu seiringan dengan berkembangnya zaman dan pertumbuhan jumlah penduduk maka teknologi sangat diperlukan oleh manusia. Terbukti pada saat ini tenaga manusia lebih sedikit dibutuhkan dan digantikan dengan tenaga mesin yang lebih cepat dan lebih kuat dibandingkan dengan tenaga manusia. Perkembangan teknologi sebagaimana telah peneliti uraikan di atas mendatangkan beragam keuntungan atau dampak positif bagi manusia, kendatipun demikian, akibat perkembangan teknologi tersebut muncul pula beragam dampak negatif. Robert $\mathrm{P}$. Borrong mengatakan bahwa "kerusakan lingkungan terjadi pada waktu umat manusia bergerak meninggalkan kehidupan alamiah ke arah kehidupan yang direkayasa sesuai keinginannya" 22

Sejak abad ke 20 hingga abad ke 21 ini umat manusia disadarkan dengan berbagai masalah yang berkaitan langsung dengan kelangsungan hidupnya sehingga manusia kemudian menemukan bahwa semua masalah itu adalah akibat dari perlakuannya terhadap lingkungan biologisnya yang kurang beretika

17 L. Santoso A.Z, 500.

18 Ibid, 503.

${ }^{19}$ Kata Ilmu.com, Diakses pada hari Sabtu, 18 April 2020 jam 16.15 di Plalar

${ }^{20}$ L. Santoso A.Z., 501-504.

${ }^{21}$ https://id.wikipedia.org/wiki/Revolusi Hijau, diakses pada hari kamis di Plalar, 19/03/2020, pukul 19.12

${ }^{22}$ Robert P. Borrong, 42 
sehingga terjadi banyak masalah yang berdampak langsung kepada manusia, khususnya kesehatan manusia dan kelangsungan hidupnya. Kesadar-an ini membuahkan hasil pemikiran untuk berbalik dari sifat ekploitatif kepada sifat rekonstruktif, khususnya dalam hal pertanian.

\section{Eksegesa Kejadian 2:15 Sebagai Tinjauan Teologis}

1. Analisa Teks dan Terjemahan

a. Teks Bahasa Indonesia

2:15 TUHAN Allah mengambil manusia itu dan menempatkannya dalam taman Eden untuk mengusahakan dan memelihara taman itu.

b. Teks Bahasa Ibrani

2:15 versi Hebrew Old Testastament Tranlsation (WTT) adalah

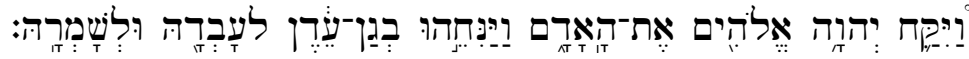

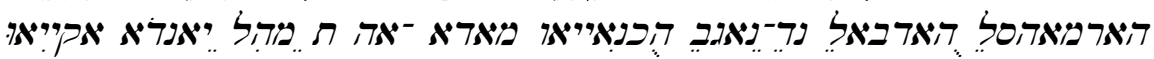

c. Teks Bahasa Inggris (KJV) 2:15 And the LORD God took the man, and put him into the garden of Eden to dress it and to keep it.

2. Latar Belakang Kitab Kejadian

Kitab Kejadian adalah kitab pertama dalam Alkitab. Kitab ini digolongkan dalam satu bagian dengan ke-empat kitab taurat lainnya sehingga disebut Pentateukh. Dalam bahasa Ibrani kata "kejadian" adalah beresit. Menurut tafsiran alkitab perjanjian lama masa kini 1 mencatat bahwa "orang Yahudi menyebut kitab pertama dari Taurat ini beresit yang berarti pada mulanya"23 yang berarti awal"24. Kitab Kejadian merupakan kitab yang menceritakan asal usul dunia dan manusia, pula merupakan kesaksian iman yang isinya terutama mengenai siapa Allah dan bagaimana la bekerja dalam kehidupan manusia sejak penciptaan dunia.

Crawford mengatakan bahwa dalam Kitab Kejadian:

We find the account of the beginning of the world and man, of domestic and civil society, of liberty and law, of sin and death, of the element of true religion, of the Plan of Redemption, of the facets of human culture, of the early etnics group of man kind, of the Messianic genealogy... ${ }^{25}$

Secara sederhana Crawford mengatakan bahwa asal usul manusia dan dunia ditemukan dalam kitab Kejadian, baik itu kemasyarakatan,

\footnotetext{
${ }^{23}$ Yayasan Komonikasi Bina Kasih, Tafsiran Alkitab Masa Kini 1 (Jakarta: BPK Gunung Mulia, 1982), 76

${ }^{24}$ C. C. Crawford, Bible Study TextBook Series (USA: College Press Publishing Company, 1985). 28

25 Ibid
} 
kebebasan dan hukum, dosa dan kematian, keagamaan, rencana penebusan, kebudayaan manusia, etika dan silsilah Mesias.

Menurut Lasor dan Bush "kitab kejadian disebut beresyit pada mulanya, yaitu kata pembuka kitab tersebut. Nama ini sesuai, karena kitab ini menceritakan awal dari segala sesuatu yang berhubungan dengan iman umat Allah dalam Alkitab"26 Berdasarkan penjelasan Crawford, Lasor dan Brush, peneliti menyimpulkan bahwa kitab Kejadian adalah kitab yang menceritakan secara ringkas asal usul dunia dan segala aspek yang ada di dalamnya, serta segala kekayaan alamnya; Mesopotamia misalnya, tempat dimana peradaban berkembang pesat di seluruh pinggir sungai Tigris dan Efrat, sebagai sumber kehidupan bagi masyarakat Mesopotamia pada saat itu. Mengutip pernyataan Thomas Berry, Tucker mengatakan: "Kebudayaan-kebudayaan terdahulu muncul di daerah-daerah yang sangat baik untuk memperkenankan pertanian pada skala besar bagi populasi yang meningkat." 27

Pernyataan di atas menunjukan bahwa kitab Kejadian benar merupakan kitab yang pertama dan merupakan sumber terpercaya terkait dengan asal usul dunia dan kehendak Tuhan atasnya. Berdasarkan hal itu, terkait dengan perkembangan dunia saat ini dan kerusakan yang ada, peneliti menyimpulkan bahwa satu-satunya cara untuk memulihkan alam sekitar kita adalah dengan melihat kembali apa rencana Tuhan dalam penciptaan.

3. Tujuan Kitab Kejadian

Kitab Kejadian sebagai Kitab pertama dalam Alkitab, ditulis dengan tujuan agar manusia mengerti bahwa alam semesta dan segala isinya tidak ada dengan sendirinya tetapi ada satu pribadi yang menciptakan semuanya itu.

Latar belakang kitab Kejadian menceritakan tentang bagaimana karya Allah yang begitu besar tidak tertandingkan oleh manusia mana pun. Ini menunjukan betapa Allah adalah Allah yang maha segalanya. Hal ini menunjukan bahwa apapun yang ingin dilakukan oleh manusia di dunia harus selalu mengikuti kehendak daripada Sang Pencipta.

4. Analisa Teologis Kitab Kejadian 2:15

Kitab Kejadian pasal 2: 15 berbicara khusus tentang tugas manusia di Taman Eden sebelum kejatuhannya ke dalam dosa. Bob Utley mengatakan

26 S. W. Lasor dkk, Pengantar Perjanjian Lama 1 Taurat dan Sejarah (Jakarta: BPK. Gunung Mulia, 1993). 111

${ }^{27}$ Mary Evelyn Tucker dan John A. Grim, Agama, Filsafat, dan Lingkungan Hidup, (Yogyakarta: Kanisius, 2003) 296 
bahwa "bekerja merupakan tugas manusia sebelum kejatuhan dan bukanlah akibat dari dosa (Work was mankind's task before the fall and not a result of $\sin )^{\prime 28}$ Pernyataan Bob sangat penting supaya tidak terjadi kesalahan persepsi dalam kaitannya antara dosa dan bekerja.

Kitab Kejadian pasal 1:31 menyatakan bahwa sungguh segala sesuatu yang diciptakan Allah sangat baik. Uniknya, Allah menyatakan hal itu bahkan sebelum taman Eden. Selanjutnya Allah membuat taman di Eden kemudian mengambil dan menempatkan manusia yang diciptakan-Nya itu di sana untuk mengusahakan dan memelihara taman itu.

Kitab Kejadian 2:15 mengatakan: TUHAN Allah mengambil manusia itu dan menempatkannya dalam taman Eden untuk mengusahakan dan memelihara taman itu. Ayat ini sering kali dikontraskan dengan ayat 28 Kejadian pasal 1 yang mengatakan: Allah memberkati mereka, lalu Allah berfirman kepada mereka: "Beranakcuculah dan bertambah banyak; penuhilah bumi dan taklukkanlah itu, berkuasalah atas ikan-ikan di laut dan burung-burung di udara dan atas segala binatang yang merayap di bumi."

Kebenaran daripada kedua pernyataan di atas adalah tidak ada kontadiksi antara kedua ayat tersebut, sebab secara konteks kedua ayat tersebut dicatat sebelum kejatuhan manusia yang berarti ia (manusia itu) masih secara sempurna hidup dalam gambar dan rupa Allah (memiliki pikiran Allah) sehingga kata berkuasa tidak bermakna berlaku brutal atas ciptaan lain melainkan mengusahakannya dengan kasih.

5. Eksegesa Kejadian 2:15

Kata kunci ayat ini yang akan peneliti eksegesa adalah Allah, Manusia, Menempatkan, mengusahakan, dan memelihara. Dengan harapan agar menemukan hubungan antara manusia dengan alam sebagai ciptaan Allah yang diciptakan dengan tujuan sebagaimana yang dikatakan oleh Henry C. Thiessen yaitu:

"Untuk mempertunjukan kemuliaan-Nya (Mazmur 8:2 Ya TUHAN,

Tuhan kami, betapa mulianya nama-Mu di seluruh bumi! Keagungan-Mu yang mengatasi langit dinyanyikan), dan untuk menerima kemuliaan. (Maz 29:1-2 Kepada TUHAN, hai penghuni sorgawi, kepada TUHAN sajalah kemuliaan dan kekuatan! Berilah kepada TUHAN kemuliaan nama-Nya,...)"29

Rasul Paulus dalam suratnya kepada jemaat di Roma mengingatkan mereka bahwa segala sesuatu datangnya dari Tuhan (Roma 11: 36 Sebab

${ }^{28}$ Bob Utley, free Bible Commentery 2018

${ }^{29}$ Henry C. Thiessen, Teologi Sistematika (Malang: Gandum Mas, 2015) 181-182 
segala sesuatu adalah dari Dia, dan oleh Dia, dan kepada Dia: Bagi Dialah kemuliaan sampai selama-lamanya!).

Pernyataan di atas menjadi dasar manusia dalam memelihara lingkungannya sebab alam dan segala isinya memang dipercayakan kepada manusia sebagai "wakil Allah atau raja muda untuk memerintah dengan hak bebasnya namun dalam kesadaran sebagai gambaran Allah" sebagaimana yang di katakan oleh Mathew Henry dalam komentarnya terhadap Kejadian 1:28 (Let us make man in our image, and let him have dominion. As he has the government of the inferior creatures, he is, as it were, God's representative, or viceroy, upon earth; ... Yet his government of himself by the freedom of his will has in it more of God's image than his government of the creatures.)"30

Pernyaan Matthew Henry dan Henry C. Thiessen di atas menunjukan suatu kolaborasi yang baik bahwa manusia memang berkuasa atas alam namun tidak semena-mena, melainkan memperlakukannya sebagaimana Allah menghendakinya, yaitu untuk menunjukan kemuliaan-Nya dan menerima kemuliaan daripada ciptaan-Nya.

\section{Allah Mengambil Manusia}

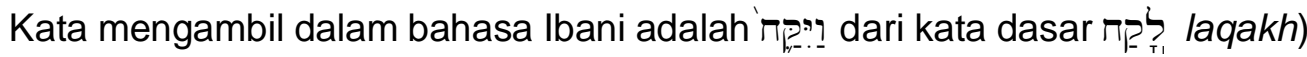
yang diterjemahkan ke dalam bahasa Inggris take"31. Kata take apabila diterjemahkan ke dalam bahasa Indonesia mengandung makna ganda yaitu mengambil dan mencabut sebagaimana yang diungkapkan oleh Yunus. la mengatakan: "... cabutlah kiranya nyawaku..." (Yun 4:3)

Willem A. Van Gemeren memberikan definisi yang sama mengenai kata xq;' sebagai take, namun ia menambahkan satu kata lain yaitu "grasp"32 Yang berarti to take and hold it stongly"33 (mengambil dan dipegang dengan erat) oleh karena itu, secara literal manusia tidak berhak atas dirinya sendiri, melainkan Tuhan. Pula, berdasarkan konteks kitab Kejadian 1-2 dan definisi di atas, otoritas sepenuhnya berada pada Allah sendiri yaitu Allah sang pencipta segala sesuatu.

\footnotetext{
${ }^{30}$ BibleWorks, Kejadian 1:28

${ }^{31}$ D.L. Baker dan A.A Sitompul, Kamus Singkat Ibrani-Indonesia (Jakarta: BPK Gunung Mulia, 2011) 35

${ }^{32}$ Willem A. VanGemer, Dictionari of Old Testament Theology and Exegisis Volume 2 (USA, ZondervanPublishingHouse, 1997) 812.

${ }^{33}$ Merriam Webster Dictionary, diakses pada hari selasa 11/02/2020 di STTJKI, jam 13.35
} 
Allah mengambil dan memegang manusia itu dengan erat sebagai bentuk perlindungan dan kasih atas manusia dan menempatkannya di taman Eden untuk melanjutkan pekerjaan Allah yang begitu baik (Kej 1:31) yang telah dikerjakan oleh Allah dengan cara memeliharanya sebab kitab Kejadian 2:13 menceritakan bahwa Allah telah menyelesaikan pekerjaan-Nya yang sungguh sangat indah (Kejadian 1:31) kemudian la berhenti dan memberkati serta menguduskan hari ketujuh tersebut. Selanjutnya Allah membuat taman Eden, mengambil manusia yang diciptakan-Nya dan menempatkannya di taman itu untuk mengusahakan dan memelihara taman itu.

Allah memegang manusia dengan erat sebagai bentuk perlindungan dan pemeliharaan-Nya kepada manusia sebagai penanggung jawab atas ciptaan lain begitu pula seharusnya manusia memegang erat ciptaan lain dengan cara memeliharanya.

\section{Manusia Berasal Dari Tanah}

Manusia dalam bahasa Ibrani adalah אָד , menurut Bob Utley kata Adam berasal dari kata Adamah, dan kata itu merupakan istilah yang digunakan oleh orang-orang Ibrani untuk tanah. "man" This is the Hebrew word "Adam", which is an obvious play on the Hebrew term for ground, adamah. The term may also imply "redness" or "blood". Many scholars believe that this refers to humanity being formed out of the red clods or clay of the Tigris/Euphrates River valley." ${ }^{4}$ Bob melanjutkan penjelasanya bahwa bagi orang Israel kuno yang membaca atau mendengar kata adam/adamah akan berpikir bahwa kata itu berbicara soal fungsi dan bukan ontologi (hakikat hidup) dari kata itu. "The ancient Israelites who read/heard this account would think of function not ontology." ${ }^{35}$ Namun pemahaman mengenai kata adam (manusia) saat ini jauh dari pemahaman orang Israel kuno; manusia melihat dirinya secara ontologis sehingga akibatnya adalah kesalahan penggunaan kewenangan.

Kenyataan bahwa manusia berasal dari tanah (Kejadian 2:7, 3:19) menunjukan bahwa manusia dan alam adalah keluarga. Dalam bahasa Yunani kata yang dipakai untuk lingkungan hidup adalah oikos yang berarti rumah. Fakta tinggal bersama di dalam satu rumah sering disebut sebagai keluarga. Manusia (Adam) bukan saja tinggal dalam satu oikos bersama ekosistem lainnya sebagai pendatang, melainkan ia adalah bagian dari alam itu sebab ia terbuat dari tanah. Dengan demikian kehidupan manusia dan ekosistem lainnya saling berkaitan dan berketergantungan. Sonny Keraf mengatakan:

${ }^{34}$ Bob Utley

35 Ibid 
Ekologi bukan semata-mata berurusan dengan pencemaran. la juga bukan semata-mata persoalan tentang kerusakan alam. Lingkungan hidup atau ekologi mengandung pengertian yang lebih luas, lebih mendalam dan lebih filosofis menyangkut kehidupan dan interaksi yang terjalin di dalamnya. la menyangkut mata rantai jaring makanan dan siklus yang menghubungkan satu kehidupan dengan kehidupan lainnya dan interaksi antara semua kehidupan dengan ekosistemnya, dengan bumi tempat hidup semua kehidupan. Singkatnya, ekologi berbicara tentang kehidupan dan jaringan kehidupan yang terdiri dari jaringan di dalam jaringan ${ }^{36}$

Kenyataan ini seharusnya menyadarkan manusia agar melakukan rekonsiliasi dengan alam sebagai keluarga yang tinggal dalam satu oikos demi mewujudkan tujuan Allah dalam menciptakan alam dan segala isinya.

\section{Allah Menempatkan Manusia di Taman Eden}

Kata menempatkan dalam bahasa Ibrani adalah נוח (yanach) dan diterjemahkan ke dalam bahasa Inggris menjadi settle. Kata settle mengandung makna "to place as to stay",37 Dalam alkitab bahasa Indonesia, kata yang dipakai adalah menempatkan. Apabila diterjemahkan dari kata to place as to stay maka mengandung makna ditempatkan untuk tinggal. Oleh karena itu berdasarkan kata ini peneliti menyimpulkan bahwa Tuhan sesungguhnya menempatkan manusia dalam taman Eden dengan harapan agar menusia itu tinggal dalam tempat yang nyaman baginya. Berdasarkan definisi di atas, peneliti mengambil kesimpulan bahwa sejak awal Tuhan Allah telah mengambil dan menetapkan manusia pada lingkungan yang baik supaya manusia bekerja dengan aman dan nyaman. la tidak mengehendaki manusia mengalami penderitaan. la senantiasa merencanakan dan mempersiapkan yang terbaik bagi manusia. la berfirman melalui nabi Yeremia kepada manusia (bangsa Israel) bahwa "la merencanakan damai sejahtera dan bukan kecelakaan untuk memberikan kepada manusia (bangsa Israel) hari depan yang penuh harapan" (Yer 29:11). Peryataan ini tidak saja pada waktu bangsa Israel tertindas oleh raja Nebukadnezar sehingga Tuhan menguatkan bangsa Israel melainkan pernyataan tersebut merupakan sifat dan tujuan utama Allah menciptakan umat manusia. Oleh sebab itu, apabila saat ini manusia mengalami masalahah dalam hal ini krisis ekologi, itu bukan karena nasib atau predestinasi Allah kepada manusia melainkan ulah manusia itu sendiri.

Ulah manusia yang dimaksudkan peneliti adalah akibat interpretasi yang salah terhadap kuasa yang diberikan Allah kepadanya untuk menguasai ciptaan lainnya (Kej 1:26-28). Sonny Keraf mengatakan:

${ }^{36}$ A. Sony Keraf, Filsafat Lingkungan Hidup Alam Sebagai Sebuah Sistem Kehidupan, (Yogyakarta: Kanisius, 2014) 46

${ }^{37}$ Marriam Webster 
Kejadian 1:26-28 ditafsirkan sebagai pemberian kewenangan Allah kepada manusia atas alam untuk dieksploitasi bagi kepentingannya sendiri, sehingga manusia menjadi arogan dan bertindak sebagai penguasa yang lalim atas alam ini. la (manusia) memandang alam sebagai obyek untuk dieksploitasi38

Pernyataan Sonny Keraf di atas meringkaskan bahwa permasalahan ekologis saat ini merupakan akibat ke-egoisan manusia atas alam sebagai tumpuan hidupnya. Mengutip pernyataan Alfred North Whitehead, Imanuel Geovasky dalam tulisannya tentang Respon Sudut Pandang Teologi Kristen Terhadap Krisis Ekologi : Menuju Upaya Bersama Multi-iman Menanggapi Krisis Ekologi mengatakan bahwa: "Barangsiapa menghancurkan lingkungan hidupnya, ia menghancurkan kepenuhan dirinya sendiri karena kesalingterhubungan, interaksi dan ke-saling-mempengaruhi- antara wujud aktual yang satu dan yang lain." 39 Dengan demikian dapat dipahami bahwa merusak atau mengeksploitasi alam sama artinya merusak poros kehidupan manusia yang berarti bunuh diri.

\section{Manusia Mengusahakan Tanah}

Kata yang dipakai dalam bahasa Ibrani untuk kata mengusahakan adalah עָבָ (abad/abadah) sebanyak 266 kali yang diterjemahkan dalam bahasa Inggris sebagai "work, cultivate, serve, as a slave, be a slave, keep, worship"40

Work bekerja, cultivate: mengelola, serve: melayani, as a slave: sebagai hamba atau budak, be a slave: menjadi hamba atau budak, keep: menjaga, worship: Ibadah.

Berdasarkan definisi di atas, peneliti menemukan bahwa Tuhan Allah mengambil manusia dan menempatkannya di taman Eden untuk mengusahakan taman itu dengan bekerja dan mengelolah taman itu dalam kapasitas sebagai hamba Allah. Hal itu menjadi tanggung jawab manusia bahkan sebelum manusia jatuh ke dalam dosa, sebagaimana yang dikatakan oleh Bob bahwa "Work was mankind's task before the fall and not a result of $\sin ^{\text {,41 }}$ dengan demikian manusia bekerja bukan semata-mata untuk kepentingan-nya sendiri, melainkan kepentingan Allah yaitu menjaga keindahan ciptaan yang telah diciptakan oleh Allah.

Terjemahan kata עָבַד (abad/abdah) di atas terdapat banyak arti, salah satunya adalah worship yang berarti ibadah. Kata ibadah sering dipahami sebatas melakukan hal-hal yang bernuansa spiritual dan hanya di rumah-rumah ibadat dan peduli kepada sesama manusia (antroposentris), namun berdasarkan hasil eksegesa ini peneliti menemukan bahwa ibadah tidak hanya sedangkal

\footnotetext{
${ }^{38}$ Sonny Keraf, Etika Lingkungan (Jakarta: Kompas Media Nusantara, 2005) 36-37

${ }^{39} \mathrm{https}$ ://medium.com/literasi/respon-sudut-pandang-teologi-kristen-terhadap-krisisekologi-menuju-upaya-bersama-multi-iman-a692571d8aa. diakses pada hari Kamis 19/03/2020 di STTJKI, pukul 14.00

${ }^{40}$ Bible Works, diakses pada hari Rabu 19/03/2020 di STTJKI, jam 14.15

${ }^{41}$ Bob Utley
} 
itu, melainkan peduli kepada lingkungan hidup merupakan ibadah yang mana hal ini merupakan mandat daripada Allah sendiri.

\section{Manusia Memelihara Alam}

Kata memelihara dalam bahasa Ibrani adalah שַׁَמר ((shamar). Dalam alkitab dipakai sebanyak 420 kali yang diterjemahkan ke dalam bahasa Inggris sebagai watch, guard, protect; save, retain: observe, attentively, keep.

Watch: mengawasi, Guard: menjaga, Protect: Melindungi, Save: Menyelamatkan, Retain: menjaga tetap dalam posisinya, Observe: mengawasi, Attentively: diperhatikan dengan sungguh-sungguh, Keep: Memelihara

Berdasarkan definisi kata shamar di atas, peneliti menemukan bahwa tugas manusia pada waktu di taman Eden adalah memelihara taman itu agar tetap sama (retain) sebagaimana yang telah diciptakan oleh Allah. Itu merupakan tujuan Allah. Dengan demikian, apabila manusia mampu menjaga ciptaan Allah maka ia dapat dikatakan berhasil. Oleh sebab itu, pada bagian ini peneliti menyimpulkan bahwa keberhasilan manusia bahkan hari ini, bukan karena memiliki segala sesuatu lebih daripada orang lain sebagaimana pemikiran manusia moderen, melainkan keberhasilannya adalah ketika ia mampu memelihara, melindungi, dan menyelamatkannya ciptaan Tuhan dengan baik dan sungguh-sungguh. Kata dasar memelihara adalah pelihara yang mengandung makna dijaga dan dirawat agar tidak rusak atau bahkan hilang, melainkan membuatnya berkembang lebih besar atau banyak.

Kitab Kejadian 3: 17-19 menceritakan kisah yang berbeda, dimana pada pasal 1-2 kitab kejadian menceritakan tentang keindah yang Allah ciptakan (Kej 1:31), namun dalam pasal 3:17-19 Allah justru mengutuk tanah yang diciptakan-Nya sendiri yang dinyatakan sungguh amat baik akibat ke-tidak taatan manusia. Pertanyaan, mengapa tanah yang dikutuk dan bukan manusia? Allah pada waktu menciptakan dunia dan segala isinya, la tidak terlebih dahulu menciptakan manusia, melainkan alam yang menjadi tempat dimana manusia itu akan tinggal.

Matthew Henry mengatakan "God gave the earth to the children of men, designing it to be a comfortable dwelling to them namum manusia"42 Namun tidak hanya untuk tinggal saja atau menjadi penikmat kenyamanan tanpa mengusahakannya dan memeliharannya. la wajib melakukan sesuatu demi menjaga kenyamanan itu

42 Matthew Henry: Commentary on the whole bible Volume 1 (Grand Rapids, MI: Christian Classics Ethereal Library) 66 
Crawford mengatakan: "Adam had work to do in Eden: he had been divinely enjoined to dress and to keep it, that is, the ground (Gen 2:15). After the expulsion from the Garden he was ordered to till the ground from whence he was taken (Gen 3:23)"43

Terjemahan Alkitab bahasa Indonesia untuk kata עָבָָ (abad) adalah mengusahakan dan שֵַָׁר ((shamar) memelihara. Kata mengusahakan berasal dari kata dasar usaha yang berdasarkan terjemahan kamus besar bahasa Indonesia adalah "kegiatan dengan mengarahkan tenaga, pikiran atau badan untuk mencapai suatu maksud" 44 Sementara kata memelihara berasal dari kata dasar pelihara yang mengandung arti rawat, maka ketika kata pelihara diberi imbuhan me- pada awal kata pelihara maka secara morfologi bahasa kata tersebut berubah menjadi memelihara yang berarti "menjaga dan merawat secara baik-baik" ${ }^{\prime 4}$.

Terjemahan lain Alkitab berbahasa Inggris versi King James kata בְ,' (abad) diterjemahkan dress dan שָׁמַר ((shamar) diterjemahkan keep yang mana kedua-duanya mengandung makna mengindahkan tanpa merubah keasliannya. Sementara dalam terjemahan Contemporary English Version menerjemahkan kedua kata tersebut dengan kata to take care of it and look after it yang mengandung arti yang sama sebagaimana dress and keep yaitu merawat dan menjaga agar tetap indah sebagaimana yang telah diciptakan-Nya.

Secara konteks, konten kitab Kejadian 2 adalah perintah Tuhan kepada manusia untuk mengusahakan dan memelihara taman Eden, sehingga berdasarkan definisi di atas peneliti menyimpulkan bahwa manusia diwajibkan untuk mengusahakan taman itu sekuat tenaga sesuai dengan kehendak Allah, mengingat pada saat itu manusai belum melanggar ketetapan Tuhan. la masih secara sempurna serupa dan segambar dengan Allah (Kej 1:26-27).

Sebagaimana peneliti ungkapkan di atas bahwa pada waktu manusia belum berdosa ia mengusahakan dan memelihara alam secara benar berdasarkan pandangan Allah sebab ia belum berdosa; bagaimana dengan manusia memelihara alam setelah ia berdosa? Crawford mengatakan "Even to fallen menkind, honest is a great blessing" ${ }^{\text {"46 }}$ (bahkan kepada manusia yang manusia berdosa sekalipun, kejujuran merupakan suatu berkat besar). Pernyataan Crawford menunjukan bahwa, sekalipun manusia telah berdosa, tetapi apabila dalam diri manusia ada keinginan untuk melakukan hal yang baik

\footnotetext{
${ }^{43}$ Crawford, 335.

${ }^{44} \mathrm{KBBI}, 1538$

45 lbid., 1041

${ }^{46}$ Crawford, 335
} 
maka itu dapat menjadi berkat bagi manusia, dimana tanah yang dikutuk itu tetap dapat memberikan hasil yang memuaskan kepada manusia.

Konteks keseluruhan kitab Kejadian 1-2 berbicara tentang ketaatan manusia dalam mengerjakan tanggung jawabnya, kemudian pasal 3 manusia tidak taat (taat - tidak taat) sehingga mengakibatkan alam sebagai tempat nyaman manusia yang diciptakan oleh Allah menjadi tidak nyaman bagi manusia. Matthew Henry mengatakan:

God gave the earth to the children of men, designing it to be a comfortable dwelling to them. But sin has altered the property of it. It is now cursed for man's sin; Sin turned a fruitful land into barrenness; the wilderness for his habitation, and the barren land his dwelling ${ }^{47}$

(Tuhan memberikan bumi kepada anak-anak manusia, membuatnya menjadi tempat tinggal yang nyaman bagi mereka. namun, dosa sudah merusak semuanya itu. Dikutuk oleh karena dosa manusia; Dosa mengubah tanah yang begitu subur menjadi tandus; semak belukar sebagai habitatnya dan tanah yang tandus menjadi tempat tinggalnya)

Penjelasan Matthew Henry di atas menunjukan bahwa apa yang begitu baik yang telah diciptakan oleh Allah untuk kepentingan manusia menjadi rusak akibat dosa manusia itu sendiri. Akibatnya manusia harus berjerih paya mengerjakan tanah dengan berpeluh (sweat) dengan kata lain bekerja sangat keras hingga mengeluarkan keringat.

Kisah tugas manusia mengusahakan dan memelihara alam dalam kejadian 2:15 terlihat eksotis dan menciptakan hubungan yang romantis antara manusia, alam dan Tuhan. Namun, kisah tersebut tidak berlangsung lama. Seiringnya waktu kisah indah tersebut berubah menjadi kepahitan yang mendalam dan mematikan. Manusia yang tadinya menjadi wakil Allah atau raja muda, kini harus meninggalkan tahta itu. Kejadian 3 menunjukan bagaimana kisah itu berubah dan sekaligus dampak perubahan tersebut, kemudian pasal 4 - 7 menunjukan tindakan manusia akibat kejatuhan itu. Celia Deane mengatakan "pelanggaran manusia pada batas-batas yang ditetapkan Allah dalam pasal permulaan Kejadian, atau "kejatuhan manusia, menyebabkan terganggunya hubungan antara manusia, Allah dan bumi." ${ }^{48}$ Yang tadinya romantis, kini menjadi garang dan pembunuh (Kain membunuh Habil) dan semakin jahat manusia sehingga Tuhan menghukumnya dengan air bah.

Hukuman Tuhan atas ketidak taatan manusia terlihat kejam, namun dalam setiap hukuman atau sanksi yang diberikan Tuhan kepada manusia akibat ketidak taatannya, la selalu menyediakan solusi. Ketika manusia manusia

\footnotetext{
${ }^{47}$ Matthew Henry, 66-67

${ }^{48}$ Celia Deane-Drummond, Teologi dan Ekologi (Jakarta: 2015) 23
} 
jatuh dalam dosa dan sadar bahwa ia telanjang, Tuhan membuatkan pakaian baginya, dan ketika la akan menghukum manusia dan segala isinya dengan air bah la juga menyediakan solusi yaitu melalui Nuh untuk membuat bahtera baginya dan keluarannya sehingga ia dan keluargannya tidak ikut dimusnahkan oleh kedasyatan air bah itu.

Kasus rusaknya hubungan manusia, alam, dan Tuhan menyebabkan semakin garangnya manusia terhadap alam sebagai saudara dengan cara mengeksploitasinya demi kepentingannya sendiri. Namun pada kasus inipun, Tuhan sendiri yang berinisiatif melakukan rekonsiliasi itu dengan cara mengutus Yesus Kristus datang ke dalam dunia 2000 tahun lalu untuk mendamaikan kembali manusia dengan Allah penciptanya. Melalui rekonsiliasi yang dilakukan oleh Allah dengan manusia memberikan kemungkinan agar manusia dapat pula berdamai kembali atau rekonsiliasi kembali dengan ekologi.

Kenyataan bahwa Allah mengambil manusia dan menempatkannya di taman Eden untuk mengusahakan dan memelihara taman itu menunjukan bahwa manusia tidak memiliki hak untuk memperlakukan ekosistem lainnya semenamena, melainkan dalam satu kesadaran bahwa ia adalah wakil atau raja muda yang ditunjuk untuk memerintah atas ciptaan lainnya dalam rangka mewujudkan rencana Allah yaitu menunjukan kemuliaan-Nya dan menerima kemuliaan daripada ciptaan-Nya. Kendatipun berjalannya waktu rencana itu terlihat gagal, namun Allah tidak tinggal diam, atas inisiatif-Nya sendiri la melakukan rekonsiliasi dengan manusia yang menyebabkan rusaknya hubungan itu. Dengan demikian memberikan contoh kepada manusia untuk berdamai kembali dengan alam sebagai bentuk kecintaannya kepada Tuhan dalam rangka mewujudkan rencana Allah.

Tidak berarti tanpa rekonsiliasi kembali dengan manusia dan manusia dengan alam, rencana Allah untuk menunjukan kemuliaan-Nya dan menerima kemuliaan dari ciptaanNya tidak akan terwujud; melainkan menunjukan bahwa Allah bukanlah Allah yang semena-mena. Sabab la dapat memusnahkan semuanya seketika dan menciptakan produk baru. Namun melalui situasi kejatuhan ini la menujukan bahwa la adalah Allah yang menciptakan sekaligus merawat apabila terdapat kerusakan atau masalah di dalamnya.

\section{Pertanian Organik Sebagai Bentuk Tanggung Jawab Manusia Terhadap Lingkungannya}

\section{Pengertian Pertanian Organik}

Secara umum sistem pertanian disebut pertanian organik apabila proses produksi pangan dan produk pertanian lain adalah alamiah, tidak menggunakan pupuk dan pestisida kimia sintetis, hormon buatan, antibiotik dan bahan-bahan 
kimia lainnya. Dengan demikian maka sistem pertanian tersubut dapat disebut sebagai pertanian organik.

Berdasarkan definisi, kata Pertanian mengandung makna "mengusahakan tanah dengan tanam-menanam." ${ }^{\prime 9}$ Sedangkan Organik adalah "zat yang berasal dari makhluk hidup, tumbuhan; atau yang berhubungan dengan organisme" ${ }^{50}$ Jadi Pertanian Organik adalah sistem pengolahan tanah dengan tujuan tanam-menanam dengan memanfaatkan atau menggunakan zat yang berasal dari makhluk hidup dan tumbuhan. Pengertian yang lebih sempit tentang pertanian organik yang umumnya dikenal dalam kalangan petani disebut sebagai sistem pertanian bebas kimia.

\section{Pandangan Kristen Tentang Pertanian Organik}

Pandangan Kristen terkait dengan pertanian organik tidak bertentangan dengan pandangan pada umumnya, akan tetapi kekristenan tidak melihat pertanian organik sebatas perlakukan secara alamiah, melainkan dasar pertanian organik menurut iman Kristen adalah kasih, kesabaran, ketulususan, dan sebagai bentuk bukti percayanya kepada Allah pencipta jagad raya. Daniel Rudolph selaku organic farming developer di Dususn Kaliduren mengatakan bahwa:

Bertani secara organik sesungguhnya berarti petani sedang menyelamatkan ekosistem alam dan generasi sekarang bahkan generasi yang akan datang. Hal ini sangat alkitabiah sebab dalam hukum kasih secara vertikal aplikasinya adalah kepedulian terhadap segala ciptaan Tuhan, sedangkan secara horizontal aplikasinya adalah kepedulian terhadap sesama ${ }^{51}$

Bertalian dengan hal itu, dalam sebuah forum lokakarya dalam rangka menpersiapkan calon petani organik yang diadakan oleh Yabima Indonesia (Yayasan Bina mandiri Indonesia) dengan tema Pertanian Organik Adalah Tindakan Iman yang dihadiri oleh beragam kepercayaan. Pada sesi diskusi kelompok calon petani organik Kristen mengemukakan berdasarkan alkitab bahwa hal yang mendorong mereka untuk bertani organik, adalah:

Kasih (Matius 22:37-40); kesabaran, karena ada banyak tantangan dalam pertanian organik (Galatia 5:22); manusia perlu bersyukur dalam segala hal termasuk melestarikan (1 Tesalonika 5:18); ketulusan (Matius 10:16); percaya akan Sang Pencipta dengan kekuatan dan semangat yang sudah diberikan (Matius 17:20);

\footnotetext{
49 Tim Redaksi, Kamus Besar Bahasa Indonesia Edisi Keempat, (Jakarta: Gramedia Pustaka Utama, 2008), 1401

${ }^{50}$ Aplikasi Kbbi Offline

${ }^{51}$ Wawancara dengan Daniel R Rudolp, pada hari Jumat, tanggal 24 Maret 2019, Jam 17.45
} 
pembebasan dari segala kutuk, berkat bagi ciptaan, ada istirahat untuk tanah supaya pulih lagi (Imamat 25:4, 11, 28). ${ }^{52}$

Sepintas temuan diskusi kelompok di atas tidak ada kaitannya dengan pertanian organik. Namun perlu diketahui bahwa segala sesuatu yang dilakukan tanpa dasar yang benar akan berakhir dengan hasil yang tidak benar pula. Perlakuan ekologis atas dasar antroposentris misalnya. Sebab itu, kasih, kesabaran, ketulusan dan percaya kepada Allah harus menjadi dasar dalam memperlakukan segala sesuatu, dalam hal ini adalah pertanian organik. Paulus menulis kepada jemaat di Kolose agar mengerjakan segala sesuatu dengan segenap hati seperti untuk Tuhan dan bukan untuk manusia (Kolose 3:23)

Pernyataan di atas selaras dengan pernyataan Borrong bahwa:

Manusia dan semua makhluk hidup lainnya, bahkan seluruh planet bumi ini, bersumber dari Allah. Allah yang menciptakannya dan Allah menghendaki seluruhnya berada, topang- menopang, dan saling membutuhkan. Kita perlu menjaga dan memelihara lingkungan hidup bukan saja karena kita membutuhkan sumbersumber di dalamnya dan karena bumi ini adalah rumah kita (antroposentris), bukan pula karena makhluk hidup memiliki hak asasi seperti hak asasi manusia (biosentris), juga bukan karena bumi ini merupakan suatu ekosistem yang memiliki nilai intrinsik (ekosentris); kita perlu menjaga dan memelihara lingkungan hidup karena lingkungan hidup adalah ciptaan Allah, termasuk manusia, yang diciptakan untuk hormat dan kemuliaan- Nya (Teosentris). ${ }^{53}$

Mengutip pernyataan Skolimowski, penulis Jurnal Sosial Humaniora (JSH) mengatakan bahwa:

Kita manusia adalah manusia spriritual yang hidup, oleh karena itu dalam Kapasitas spiritual manusia sebagai ciptaan Tuhan seharusnya membuat manusia peka dan sadar diri untuk membina kualitas hubungan yang spiritual dengan ciptaan lain entah itu hubungan manusia dengan manusia, maupun hubungan manusia dengan alam. Dimensi spiritual merupakan instrumen yang mengarahkan sikap/tindakan manusia dalam relasi manusia dengan entitas yang lain dalam alam secara bermoral. Dimensi spiritual memungkinkan manusia untuk hidup secara rohani dalam menghayati totalitas eksistensinya dalam alam. ${ }^{54}$

Tidak dapat disangkal bahwa keterikatan manusia dengan alam membuat manusia bertanggung jawab penuh akan kelestarian alam di sekitarnya (Kejadian 2:15). Mengusahakan yang dimaksudkan peneliti dalam Kejadian

52 https://yabima.org/2018/01/pertanian-organik-adalah-tindakan-iman. Diakses di Plalar, pada hari Jumat, tanggal 24 Mei 2020, pukul $19.00 \mathrm{Wib}$

${ }^{53} \mathrm{https}$ ://reformed.sabda.org/etika lingkungan hidup dari perspektif teologi kristen.

Diakses di Plalar pada hari Jumat, tanggal 24 Mei 2020 pukul 19.27

${ }^{54}$ Jurnal Sosial Humaniora (JSH) 44-45 
2:15, ialah manusia sebagai citra Allah seharusnya memanfaatkan alam sebagai bagian dari ibadah dan pengabdiannya kepada Allah. Dengan kata lain, penguasaan atas alam seharusnya dijalankan secara bertanggung jawab: memanfaatkan sambil menjaga dan memelihara.

Robert P Borrong mengatakan "lbadah yang sejati adalah melakukan apa saja yang merupakan kehendak Allah dalam hidup manusia, termasuk hal mengelola ("abudah") dan memelihara ("samar") lingkungan hidup yang dipercayakan kekuasaan atau kepemimpinannya pada manusia." 55

Kesimpulan dari semua paparan di atas terkait pandangan Kristen tentang pertanian organik adalah tindakan bercocok tanam yang sifatnya Teosentris sebagai bentuk ungkapan cintan kepada Allah dengan menerapkan hukum kasih, kesabaran, ketulusan serta percaya bahwa "pertanian organik adalah kehendak Allah." 56 Kesadaran ini yang akan mendorong seseorang untuk bertani dengan memikirkan kelansungan hidup ekosistem lainnya yang beradara di sekitarnya.

\section{Tujuan Pertanian Organik}

Tantangan penerapan pertanian organik sangat besar. Oleh sebab itu sebagaimana peneliti jelaskan dalam bagian pendahuluan terkait dengan alasan pertanian konvensional adalah karena petani tidak mengetahi hal-hal terkait pertanian organik. Sebab itu agar menjadi menarik untuk melakukan pertanian organik petani perlu mengetahui tujuan dan bagaimana bertani organik.

Tujuan dari pada pertanian organik berdasarkan IFOAM adalah sebagai berikut

1. Menghasilkan produk pertanian yang berkualitas dengan kuantitas memadai.

2. Membudidayakan tanaman secara alami

3. Mendorong dan meningkatkan siklus hidup biologis dalam ekosistem pertanian

4. Memelihara dan meningkatkan kesuburan tanah jangka panjang

5. Menghindarkan seluruh bentuk cemaran yang diakibatkan penerapan teknik pertanian

6. Memelihara keragaman genetik sistem pertanian dan sekitarnya.

7. Mempertimbangkan dampak sosial dan ekologis yang lebih luas dalam sistem usaha tani.

${ }^{55}$ Ibid., Jam 10:46

${ }^{56}$ Yebima, Jam 11:42 
Tujuan pertanian di atas harusnya menjadi daya tarik bagi para pelaku pertanian, sebab pertanian organik sesungguhnya menghasilkan nilai-nilai positif yang sifatnya long turm dan luas yang akan menimbulkan kenyamanan bagi pelaku pertanian dan orang lain.

\section{Prinsip-Prinsip Pertanian Organik}

a. Prinsip Pertanian Organik berdasarkan Kejadian 2:15

Kejadian 2:15 menguraikan bahwa Tuhan Allah mengambil manusia itu (Adam) dan menempatkannya dalam taman Eden untuk mengusahakan dan memelihara taman itu. Berdasarkan hasil eksegesa, peneliti menemukan bahwa Tuhan Allah memerintah manusia itu untuk mengusahakan dan memelihara taman Eden dengan menyadari akan pentingnya kesehatan ekosistem alam serta menyadari bahwa ekosistem alam bersifat simbiosis mutualisme atau saling berketergantungan antara satu dengan yang lain dan berdampak langsung kepada manusia sebagai mikrokosmos yang lebih tinggi derajatnya dari makrokosmos maka harus melindungi makrokosmos yang rantai kehidupannya bergantung pada perlakuan manusia. Baik buruknya manusia bergantung pada perlakuannya terhadap alam yang ia huni, oleh sebab itu ia harus mengusahakan alam dengan berlaku adil terhadap ciptaan yang lain sebagai makrokosmos.

Secara sederhana Tuhan Allah menempatkan manusia itu untuk mengusahakan dan memelihara alam ciptaan-Nya dengan menerapkan beberapa prinsip, antara lain: Prinsip kesehatan, ekologi, perlindungan dan keadilan. Diagram di bawah ini secara singkat menggambarkan bagaimana prinsip-prinsip tersebut ditemukan.

Dalam penerapan sistem pertanian organik, prinsip utamanya adalah untuk memberikan kesehatan kepada produsen, konsumen, lingkungan sekitar, tanah dan ekosistem alam. Menurut salah satu mahasiswa Universitas Sebelas Maret (UNS) dalam penelitiannya tentang pertanian organik di Boyolali mengatakan bahwa: "Kesehatan merupakan bagian tak terpisahkan dari bagian kehidupan." 57 Untuk memperoleh tubuh yang sehat dan hidup yang sejahtera serata memelihara kelangsungan hidup ekosistem, pertanian organik merupakan pilihan terbaik untuk mencapai tujuan tersebut, sebab pertanian organik mampu menghasilkan makanan yang bermutu tinggi dan bergisi yang dapat mendukung pemeliharaan kesehatan dan kesejahteraan.

\footnotetext{
${ }^{57} \mathrm{Https}$ ://Digilib.Uns.Ac.Id/Dokumen/Download/50110/Mjaxodaz/Sistem-PengelolaanPertanian-Padi-Organik-Di-Desa-Cepokosawit-Kecamatan-Sawit-Kabupaten-Boyolali-Babli.Pdf Diakses Di Sttjki, 30/10/19, pukul 11:05.
} 
Pertanian Organik Sebagai Bentuk Tanggung Jawab Manusia Terhadap Lingkungannya Ditinjau Dari Kejadian 2:15 | Patrisius Tauho 
Prinsip kesehatan Menurut IFOAM (2005) adalah

Organic Agriculture should sustain and enhance the health of soil, plant, animal, human and planet as one and indivisible. This principle points out that the health of individuals and communities cannot be separated from the health of ecosystems - healthy soils produce healthy crops that foster the health of animals and people. Health is the wholeness and integrity of living systems. It is not simply the absence of illness, but the maintenance of physical, mental, social and ecological well-being. Immunity, resilience and regeneration are key characteristics of health. The role of organic agriculture, whether in farming, processing, distribution, or consumption, is to sustain and enhance the health of ecosystems and organisms from the smallest in the soil to human beings. In particular, organic agriculture is intended to produce high quality, nutritious food that contributes to preventive health care and well-being. In view of this it should avoid the use of fertilizers, pesticides, animal drugs and food additives that may have adverse health effects. ${ }^{58}$

IFOAM menjelaskan bahwa pertanian organik harus melestarikan dan meningkatkan kesehatan tanah, tanaman, hewan, manusia, dan bumi sebagai satu kesatuan dan tak terpisahkan. Prinsip ini menunjukkan bahwa kesehatan tiap individu dan komunitas tak dapat dipisahkan dari kesehatan ekosistem, tanah yang sehat menghasilkan hasil panen yang sehat yang membantu kesehatan hewan dan manusia. kesehatan adalah itegritas utama dari semua sistem kehidupan. Ini tidak berarti ketiadaan penyakit, melainkan pengelolaan fisik, mental, sosial dan kesejahteraan ekologi. Peran pertanian organik baik dalam produksi, pengolahan, distribusi, atau konsumsi konsumsi bertujuan untuk melestarikan dan meningkatkan kesehatan ekosistem dan organisme, dari yang terkecil yang berada di dalam tanah hingga manusia, serta dimaksudkan untuk menghasilkan makanan bermutu tinggi dan bergizi yang mendukung pemeliharaan kesehatan dan kesejahteraan. Oleh karena itu harus dihindari penggunaan pupuk, pestisida, obat-obatan bagi hewan dan bahan aditif makanan yang dapat berefek merugikan kesehatan atau segala jenis kimia sintetis.

Dalam hal ini, peran utama pertanian organik baik dalam produksi, pengolahan, distribusi, dan konsumsi adalah meningkatkan kesehatan ekosistem dan organisme dari yang terkecil baik yang kelihatan maupun yang tidak kelihatan secara kasat mata hingga manusia.

\section{Prinsip Ekologi}

Prinsip ekologi adalah suatu prinsip pertanian organik yang didasarkan pada sistem dan siklus ekologi kehidupan. Yang dimaksudkan dengan sistem dan

\footnotetext{
58 The IFOAM NormsFor Organic Production And Processing, (Germany, 2014), 9-10
} 
siklus ekologi kehidupan adalah proses pertanian alami (organik) sebagaimana ekologi kehidupan dimana proses sirkulasisnya dilakukan secara alami.

Prinsip ekologi menurut IFOAM (2005) adalah:

Organic Agriculture should be based on living ecological systems and cycles. It states that production is to be based on ecological processes, and recycling. Organic farming, pastoral and wild harvest systems should fit the cycles and ecological balances in nature. These cycles are universal but their operation is sitespecific. Organic management must be adapted to local conditions, ecology, culture and scale. Inputs should be reduced by reuse, recycling and efficient management of materials and energy in order to maintain and improve environmental quality and conserve resources. Organic agriculture should attain ecological balance through the design of farming systems, establishment of habitats and maintenance of genetic and agricultural diversity. ${ }^{59}$

IFOAM mengatakan Pertanian organik harus didasarkan pada sistem dan siklus ekologi kehidupan. Produksi didasarkan pada proses dan daur ulang ekologis. Budidaya pertanian, peternakan, dan pemanenan produk liar organik haruslah sesuai dengan siklus dan keseimbangan ekologi di alam. Siklus-siklus ini bersifat universal tetapi pengoperasiannya bersifat spesifik. Pengelolaan organik harus disesuaikan dengan kondisi, ekologi, budaya, dan skala lokal. Bahan-bahan asupan sebaiknya dikurangi dengan cara dipakai kembali, didaur ulang dan dengan pengelolaan bahan-bahan dan energi secara efisien guna memelihara, meningkatkan kualitas, dan melindungi sumber daya alam. Pertanian organik harus mencapai keseimbangan ekologi melalui sistem pertanian, pembentukan habitat, pemeliharaan genetik dan agricultural diversity. Dalam penerapan pertanian organik, sistem inilah yang digunakan, dimana proses produksi bahan pangan didasarkan pada daur ulang.

\section{Prinsip Keadilan}

Prinsip keadilan dalam pertanian organik merupakan satu prinsip utama yang sangat perlu untuk diperhatikan oleh setiap pelaku pertanian. Prinsip ini tidak hanya ditujukan kepada keadilan antar manusia yaitu produsen, pedagang dan konsumen, melainkan keadilan antara manusia dan lingkungannya, yaitu manusia terhadap hewan dan tumbuh-tumbuhan maupun mikroba yang ada. Prinsip keadilan menurut IFOAM (2005)

Organic Agriculture should build on relationships that ensure fairness with regard to the common environment and life opportunities. Fairness is characterized by equity, respect, justice and stewardship of the shared world, both among people and in their relations to other

59 Ibid 
living beings. Organic agriculture should provide everyone involved with a good quality of life, and contribute to food sovereignty and reduction of poverty. It aims to produce a sufficient supply of good quality food and other products. ${ }^{60}$

IFOAM mengatakan, Pertanian organik harus membangun hubungan yang mampu menjamin keadilan terkait dengan lingkungan dan kesempatan hidup. Keadilan adalah sifat sama rata, hormat, adil dan pengelolaan dunia secara bersama antara manusia dan makhluk hidup lainnya. Pertanian organik harus memberikan kualitas hidup yang baik bagi setiap orang yang terlibat, menyumbang bagi kedaulatan pangan dan pengurangan kemiskinan. Pertanian organik bertujuan untuk menghasilkan kecukupan dan ketersediaan pangan maupun produk lainnya dengan kualitas yang baik.

Pertanian organik harus dikelola secara hati-hati dan bertanggung jawab untuk melindungi kesehatan dan kesejahteraan generasi sekarang dan mendatang serta lingkungan hidup. Berkaitan dengan hal ini sebagaimana yang diungkapkan oleh Lachlan McKenzie dan Ego Lemos mengatakan bahwa Every living being has its role to play and it's function. This must be considered and respected to create a truly sustainable ${ }^{61}$.

Secara implisit, Lachlan dan Ego mengajak para pembaca untuk berlaku adil, sebab setiap kehidupan memiliki role dan fungsinya masing-masing. Dalam membangun keadilan tersebut ada tiga prinsip utama yang dipakai yaitu peduli kepada alam, peduli kepada manusia, dan peduli kepada masa depan, sebagaimana yang diungkapkan oleh Lachlan McKenzie dan Ego Lemos. Inilah keadilan. Prinsip-prinsip ini sesuai dengan prinsip alkitab tentang merawat dan memelihara alam ciptaan Tuhan.

\section{Prinsip Perlindungan}

Dalam penerapan pertanian organik, prinsip lain yang diterapkan adalah prinsip perlindungan dengan tujuan yaitu memberikan kesehatan terhadap generasi saat ini serta generasi yang akan datang dan juga memberikan kesehatan kepada lingkungan hidup.

Prinsip perlindungan dalam pertanian organik menurut IFOAM (2005), adalah Organic Agriculture should be managed in a precautionary and responsible manner to protect the health and well-being of current and future generations and the environment. Precaution and responsibility are the key concerns in management, development and technology choices in organic agriculture. Organic agriculture should prevent

\footnotetext{
60 Ibid

${ }^{61}$ Lachlan Mckenzie And Ego Lemos, Kuidadu Ba Rai, Kuidadu Ba Ema, Kuidadu Ba Futuru (East Timor, Parmatil 2008) 22
} 
significant risks by adopting appropriate technologies and rejecting unpredictable ones, such as genetic engineering. Decisions should reflect the values and needs of all who might be affected, through transparent and participatory processes. ${ }^{62}$

IFOAM mengatakan, prinsip perlindungan adalah untuk menjaga kesehatan dan kesejahteraan generasi saat ini dan yang akan datang dan lingkungan hidup. Pencegahan dan tanggung jawab merupakan hal mendasar dalam pengelolaan, pengembangan, dan pemilihan teknologi dalam pertanian. Pertanian organik harus mampu mencegah terjadinya resiko dengan menerapkan teknologi tepat guna dan menolak teknologi yang tak dapat diramalkan akibatnya, seperti rekayasa genetika (genetic engineering) dan keputusan-keputusan harus merefleksikan nilali-nilai dan kebutuhan dari semua aspek yang mungkin dapat terkena dampaknya, melalui proses-proses yang transparan dan partisipatif.

Berdasarkan pandangan Kristen, pelestarian alam merupakan tugas setiap manusia yang tidak dapat dihindari sebab berdasarkan hukum utama yang diberikan Tuhan Yesus yaitu hukum kasih. Setiap orang Kristen wajib memelihara alam dan lingkungan hidup yang merupakan tempat interaksi segala ekosistem. Bukti bahwa seseorang mengasihi Allah adalah memelihara alam di mana ia tinggal. Rainer Scheunemann dan rekan-rekannya mengatakan bahwa: "Secara ekologis, setiap makhluk hidup tergantung secara simbiosis atau berada dalam rantai kehidupan dengan makhluk yang lain"63

\section{KESIMPULAN}

Sebagai manusia yang beribadah kepada Tuhan adalah wajib untuk melestarikan alam dengan memperhatikan prinsip-prinsip yang telah diuraikan di atas.

Berdasarkan prinsip-prinsip di atas dapat dipahami bahwa manusia diciptakan dari tanah menunjukan bahwa manusia bukan makhluk surgawi atau makhluk asing dari bumi yang ditugaskan ke dunia untuk menjaga alam yang diciptakan Tuhan, melainkan ia adalah bagian daripada alam itu sendiri. Oleh karena itu, cara yang benar atau yang seharusnya dilakukan oleh manusia adalah mengusahakan alam dengan pemahaman bahwa ia dan segala ciptaan lainnya merupakan satu keluarga. Dengan demikian sebagai anggota keluarga yang lebih tinggi derajatnya seharusnya berlaku baik serta memiliki sifat peduli kepada saudaranya dengan cara memelihara semuanya untuk mewujudkan satu keluarga yang harmonis.

\footnotetext{
62 Ibid

${ }^{63}$ Rainer Scheunemann dkk, Misi Holistik Masa Kini, (Jayapura: Sekolah Tinggi Teologi GKI “I. S. Kijne, 2004) 169
} 
Salah satu cara untuk mewujudkan lingkungan hidup sebagai satu keluarga yang harmonis adalah melalui pertanian organik. Berdasarkan hasil penelitian di lapangan, peneliiti menemukan bahwa pertanian organik merupakan sebuah kegiatan yang mampu mewujudkan satu lingkungan hidup yang harmonis. Hal ini dikarenakan dalam sistem pertanian jenis ini mengandung unsur simbiosis mutualis dimana antara makro dan mikro kosmos keduanya saling menghidupi. Manusia mememelihara kehidupan ekosistem alam dan alam memberikan kehidupan kepada manusia melalui penghasil pertanian yang mencukupkan. Oleh karena itu, dengan menerapkan sistem pertanian organik maka sesungguhnya seorang pertani sudah melakukan tanggung jawabnya seperti yang dikehendaki oleh Tuhan yaitu mengusahakan alam untuk memenuhi kebutuhannya tetapi tetap memelihara kehidupan ekosistem alam. Tindakan ini merupakan ibadah yang hidup.

\section{DAFTAR PUSTAKA}

2014. The IFOAM Norms For Organic Production And Processing, Germany,

Kamus Bahasa Indonesia Offline, diakses pada hari Sabtu, 18 April 2020 di Plalar, jam 16.50

1982. Yayasan Komunikasi Bina Kasih, Tafsiran Alkitab Masa Kini 1. Jakarta: BPK Gunung Mulia.

Baker, D.L. dan Sitompul, A.A. 2011. Kamus Singkat Ibrani-Indonesia, Jakarta: BPK Gunung Mulia.

Borrong, Robert P. 2003. Etika Bumi Baru, Jakarta, Gunung Mulia

C. C. Crawford. Bible Study TextBook Series. USA: College Press Publishing Company.

Henry, Matthew. 2000. Commentary on the whole bible Volume 1. Grand Rapids, Ml: Christian Classics Ethereal Library.

Kardinan, Agus. 2014. Prinsip-Prinsip dan Teknologi Pertanian Organik. Jakarta: IAARD Press,

Keraf, Sonny. 2005. Etika Lingkungan. Jakarta: Kompas Media Nusantara.

Keraf, Sonny. 2014. Etika Lingkungan Hidup, Yogyakarta: Kanisius.

Keraf, Sony. 2014. Filsafat Lingkungan Hidup Alam Sebagai Sebuah Sistem Kehidupan, Yogyakarta: Kanisius. 
L. Santoso A.Z. 2017. Para Penggerak Revolusi, Yogyakarta: Laksaan.

Lachlan, Mckenzie and Ego Lemos. 2008. Kuidadu Ba Rai, Kuidadu Ba Ema, Kuidadu Ba Futuru East Timor, Parmatil.

Lasor, W.S., dkk. 1993. Pengantar Perjanjian Lama 1 Taurat dan Sejarah. Jakarta: BPK. Gunung Mulia.

Scheunemann, Rainer, dkk. 2004. Misi Holistik Masa Kini. Jayapura: Sekolah Tinggi Teologi GKI “I. S. Kijne.

Thiessen, Henry C. 2015. Teologi Sistematika. Malang: Gandum Mas.

Tucker, Mary Evelyn dan John A. Grim. 2003. Agama, Filsafat, dan Lingkungan Hidup, Yogyakarta: Kanisius.

Utley, Bob. 2018. free Bible Commentary Online.

Van Gemeren, Willem A. 1997. Dictionary of Old Testament Theology and Exegesis Volume 2 USA, Zondervan Publishing House.

Jurnal Sosial Humaniora (JSH). 2019Menjadi Manusia Spiritual-Ekologis Di Tengah Krisis Lingkungan., Volume 12.

https://medium.com/literasi/respon-sudut-pandang-teologi-kristen-terhadapkrisis-ekologi-menuju-upaya-bersama-multi-iman-a692571d8aa. diakses pada hari Kamis 19/03/2020 di STTJKI, pukul 14.00

Https://Digilib.Uns.Ac.Id/Dokumen/Download/50110/Mjaxodaz/SistemPengelolaan-Pertanian-Padi-Organik-Di-Desa-CepokosawitKecamatan-Sawit-Kabupaten-Boyolali-Bab-li.Pdf Diakses Di Sttjki, 30/10/19, pukul 11:05.

https://arydj.files.wordpress.com/2009/12/01-pengertian-teknologi.pdf. Diakses di Plalar pada hari Sabtu, 18/04/2020, pukul 16.15

https://www.kompasiana.com/ronald toruan Diakses di STTJKI, 17/07/2019 pukul 13.00

https://www.katailmu.com/2013/06/revolusi-hijau.html. Diakses di Plalar pada hari Sabtu, 18/04/2020 jam 16.30

https://id.wikipedia.org/wiki/Revolusi Hijau, diakses pada hari kamis di Plalar, 19/03/2020, pukul 19.12 
SIAP, Vol. 10 No.1, Juni 2021: 33-62 